\title{
Tulane
}

Tulane Economics Working Paper Series

\section{Tax Policy Measures to Combat the SARS-CoV-2 Pandemic and Considerations to Improve Tax Compliance: A Behavioral Perspective}

\author{
James Alm \\ Tulane University \\ jalm@tulane.edu \\ Erich Kirchler \\ University of Vienna \\ erich.kirchler@univie.ac.at
}

\author{
Kay Blaufus \\ University of Hanover \\ blaufus@tax.uni-hannover.de martin.fochmann@fu-berlin.de \\ Peter N. C. Mohr \\ Nina E. Olson \\ Free University of Berlin \\ peter.mohr@fu-berlin.de \\ Benno Torgler \\ Queensland University of \\ Technology \\ benno.torgler@qut.edu.au \\ Martin Fochmann \\ Free University of Berlin \\ Center for Taxpayer Rights \\ neo@taxpayer-rights.org
}

Working Paper 2102

January 2021

\begin{abstract}
Governments have taken remarkable measures during the SARS-CoV-2 pandemic in their efforts to safeguard citizens' health and the economy. As a consequence, public debts have reached unprecedented levels, which will require at some point higher taxes. Ensuring that citizens pay these taxes requires consideration of the many factors that will likely affect their tax compliance decisions. In this paper, we reflect from a behavioral economic perspective the impact of tax policy measures on the perception, evaluation, and behavior of citizens and derive considerations to devise appropriate tax policies to ensure compliance in the future. We start with speculations about citizens' views of governmental restrictions and economic stimulus measures in response to the crisis, we apply these speculations to the acceptance and perceived effectiveness of policy measures on citizens' tax compliance behaviors, and we finish with their likely impact on determinants of tax compliance. Building on the derived insights, we deduce a set of considerations to improve tax compliance and to generate the necessary tax revenues to deal with the after-effects of SARS-CoV-2 when the pandemic is under control: communication, transparency and justification of measures, access to support, service provision, audits and penalties in case of free-riding, targeted audits, building social norms of cooperation, consideration of framing effects, development of plans and strategies for the future, and anticipation of hindsight biases.
\end{abstract}

Keywords: Covid-19 crisis; Tax compliance; Tehavioral economics; Behavioral taxation JEL codes: H12; H20; H26; D91 


\title{
Tax policy measures to combat the SARS-CoV-2 pandemic and considerations to improve tax compliance: A behavioral perspective
}

\author{
James Almª Kay Blaufus ${ }^{\mathrm{b}}$, Martin Fochmann ${ }^{\mathrm{c}}$, Erich Kirchler ${ }^{\mathrm{d}}$, Peter N. C. Mohr ${ }^{\mathrm{e}}$, \\ Nina E. Olson ${ }^{\mathrm{f}}$ and Benno Torgler ${ }^{\mathrm{g}}$
}

Keywords: Covid-19 crisis, tax compliance, behavioral economics, behavioral taxation

JEL-Classification: H12, H20, H26, D91

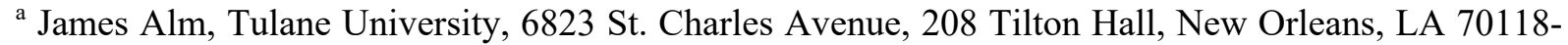
5698,USA; jalm@tulane.edu.

b Kay Blaufus, University of Hanover, Koenigsworther Platz 1, D-30167 Hanover, Germany, blaufus@tax.uni-hannover.de.

c Martin Fochmann, Free University of Berlin, Thielallee 73, D-14195 Berlin, Germany, martin.fochmann@fu-berlin.de; University of Cologne, Albertus-Magnus-Platz, D-50923 Cologne, Germany, fochmann@wiso.uni-koeln.de.

${ }^{\mathrm{d}}$ Erich Kirchler, Faculty of Psychology, University of Vienna, Universitaetsstrasse 7, A-1010 Vienna; IHS-Institute for Advanced Studies, Vienna, Austria, erich.kirchler@univie.ac.at.

e Peter N. C. Mohr, Free University of Berlin, Garystraße 21, D-14195 Berlin, Germany, peter.mohr@fu-berlin.de, WZB Berlin Social Science Center, Reichpietschufer 50, D-10785 Berlin, Germany, peter.mohr@wzb.eu.

${ }^{\mathrm{f}}$ Nina E. Olson, Center for Taxpayer Rights, Washington DC, USA, neo@taxpayer-rights.org.

${ }^{g}$ Benno Torgler, Queensland University of Technology, Level 8, Z Block, 2 George St., Brisbane, QLD 4000, Australia, benno.torgler@qut.edu.au.
} 


\title{
Tax policy measures to combat the SARS-CoV-2 pandemic and considerations to improve tax compliance: A behavioral perspective
}

\begin{abstract}
Governments have taken remarkable measures during the SARS-CoV-2 pandemic in their efforts to safeguard citizens' health and the economy. As a consequence, public debts have reached unprecedented levels, which will require at some point higher taxes. Ensuring that citizens pay these taxes requires consideration of the many factors that will likely affect their tax compliance decisions. In this paper, we reflect from a behavioral economic perspective the impact of tax policy measures on the perception, evaluation, and behavior of citizens and derive considerations to devise appropriate tax policies to ensure compliance in the future. We start with speculations about citizens' views of governmental restrictions and economic stimulus measures in response to the crisis, we apply these speculations to the acceptance and perceived effectiveness of policy measures on citizens' tax compliance behaviors, and we finish with their likely impact on determinants of tax compliance. Building on the derived insights, we deduce a set of considerations to improve tax compliance - and to generate the necessary tax revenues to deal with the after-effects of SARS-CoV-2 when the pandemic is under control: communication, transparency and justification of measures, access to support, service provision, audits and penalties in case of free-riding, targeted audits, building social norms of cooperation, consideration of framing effects, development of plans and strategies for the future, and anticipation of hindsight biases.
\end{abstract}




\section{Tax policy measures to combat the SARS-CoV-2 pandemic and considerations to improve tax compliance: A behavioral perspective}

\section{Introduction}

At the beginning of 2020, a mysterious lung disease unhinged the world. When the outbreak of the coronavirus SARS-COV-2 was hitting China, most countries observed the development with ignorance. When the first cases and then the exponential spread of infection rates were registered in Northern Italy, disavowal turned into fear and uncertainty, strong feelings of vulnerability, and loss of control. The development of the crisis evolved, following the phases of common disasters described by Zunin and Myers (2000): intense emotional reactions and a high level of activity with a low level of productivity preceded phases of solidarity and community bonding, which turned into disillusionment, anger, and reactance. The continuing stress experienced by citizens has led to physical exhaustion, and the increasing gap between need and assistance in specific branches of economic activity has led to feelings of abandonment.

The pandemic has caught citizens, businesses, and governments unprepared, forcing everyone to make decisions under uncertainty and nescience. Governments imposed lockdowns, restricted physical contacts, ordered wearing face masks in public, closed schools, mandated work from home, and disrupted businesses. The democratic form of government faces a difficult test because it must protect the inviolability of individuals' fundamental rights while also preserving the well-being of the society as a whole. The restriction of fundamental rights in the Corona crisis is, as described by German Chancellor Angela Merkel, an "imposition for democracy". Snowden (2019) argues that such regulations cast a long shadow over political history, marking a vast extension of state power into spheres of human life, providing a justification for the extension of power and control over the economy and the movement of people, authorizing surveillance and forcible detention, and affecting civil liberties (p. 81-82). He refers to the plague as an example, stressing that " $[\mathrm{w}]$ ith the unanswerable argument of a public health emergency, this extension of power was welcomed by the church and by powerful political and medical voices. The campaign against plague marked a moment in the emergence of absolutism, and more generally, it promoted an accretion of the power and legitimation of the modern state" (p. 82). An extreme current example is seen in Hungary, where the Parliament gave Prime Minister Viktor Orbán the right 
to rule indefinitely by decree, a move that critics claim used Covid-19 as a way to strengthen his power and political advantages. ${ }^{1}$

The measures taken in many countries have so far been unprecedented. Strong behavioral regulations through legal means, imposition of lockdowns, and disruption of businesses have induced significant economic costs, the magnitude of which swiftly overtook the fallout of the Great Recession. Millions of people have lost their jobs or are on short-term work arrangements, millions more have experienced economic hardship, and many businesses not only claim serious losses but risk insolvency. In the face of the pandemic and lockdown, national governments around the world have provided economic stimulus packages worth trillions of euros, throwing out the fiscal rulebook to support businesses and workers.

Ángel Gurría, secretary-general of the Organization for Economic Cooperation and Development (OECD), emphasizes the necessity of these actions, as governments must do everything they can to support people's health and the economy. ${ }^{2}$ However, once the public health crisis has finally passed, economic hardship will continue, the economic downturn will endure, and governments will need to cope with enormous national debts.

Predictions about the recovery of both the aggregate economy and different sectors are all based on extreme uncertainty. An optimistic scenario of the future builds on an assumption of rapid development and availability of a vaccination; pessimistic scenarios forecast further infection waves in the future. No option can be excluded. Nonetheless, governments need to map all possible evolutions, accept the inevitability of surprises, and equip themselves with an arsenal of appropriate strategies that can be applied flexibly as an effective response to yet unpredictable future developments. Governments also need to safeguard future revenue collection if they are to deal with the debts accumulated during the first phase of the crisis, when immediate responses were necessary to protect population health and the survival of enterprises at virtually any cost.

Public debt has reached unprecedented levels, and continues to grow despite the reopening of businesses. If governments do not anticipate cutting expenditure in the future,

\footnotetext{
${ }^{1}$ See https://www.nytimes.com/2020/04/05/world/europe/victor-orban-coronavirus.html and further examples in Chan, Ferguso, Savage, Stadelmann, and Torgler (2020).

${ }^{2}$ See https://www.law360.com/tax-authority/international/articles/1287278/tax-hikes-could-stifleeconomicrebound-oecd-chief-warns?
} 
higher taxes will be necessary to deal with the debts. The current crisis will therefore have implications for future social solidarity and cohesion, and for acceptance of plans to redistribute wealth and opportunity. Measures taken by governments to safeguard the economy and to assure tax revenue in the future may affect the tax compliance of citizens and businesses, fueling either cooperation or avoidance and evasion.

In this paper, we primarily address the following two research questions. First, what is the impact of tax policy measures taken to combat the economic consequences of the SARSCoV-2 pandemic on the perception, evaluation, and behavior of citizens? Second, what needs to be done in the future to ensure a high willingness to cooperate with the state and commitment to pay taxes in society? For this purpose, we take a behavioral economics perspective, speculating about citizens' views of governmental restrictions and economic stimulus measures in response to the crisis, the acceptance and effectiveness of policy measures, and the impact on determinants of tax behavior and consequently on tax compliance. Building on the derived insights, we close with a set of considerations to strengthen trust in authorities and their perceived power that may help contain aggressive tax avoidance and evasion when the pandemic is under control. Such considerations are one way of discussing thoughtful tax policies crucial to addressing the problems and challenges nations now face due to the Covid-19 pandemic (Craig \& Hines Jr, 2020).

The remainder of this paper is structured as follows: In section 2, we provide an overview of the most important tax policy responses from 120 countries in the face of Covid19 pandemic. In section 3, we speculate about citizens' perceptions and evaluation of these measures and identify behavioral determinants of such measures' effectiveness. In section 4, we discuss how the Corona crisis and policy measures might influence the determinants of tax behavior - mainly trust in authority and power of authority - and tax compliance. Section 5 deduces several strategies to maintain citizens' willingness to cooperate. Section 6 concludes.

\section{Tax policy measures in response to the crisis}

We begin our analysis with an overview of different countries' tax policy measures in response to the Covid-19 pandemic. The tax system tends to mitigate output fluctuations. However, the level of automatic stabilization is often considered too low (Devereux, Güçeri, Simmler, \& Tam, 2020). Thus, most countries use discretionary tax policy measures to support firm liquidity and worker employment during the crisis and to promote consumption 
and investment to overcome the crisis. Table 1 summarizes the tax policy measures taken in 120 countries by end of June 2020, based on data collected by the OECD.

Countries are using a battery of different measures to prevent companies from becoming insolvent and generating massive unemployment due to the crisis. In 99 countries, tax filing extensions and tax payment deferrals are in place, and tax waivers are operating in 27 countries. These measures usually apply to companies that were particularly hard hit by the lockdown (e.g., retail, leisure, and hospitality properties). Moreover, 23 countries offer extended tax refunds, i.e., taxpayers receive their tax refunds faster, or they can claim back the preliminary tax paid in 2019 and either pay it later or set it off against future losses. Many countries are also directly subsidizing business costs by, for example, providing nonrepayable grants to firms. To further increase business cash flow, some countries also have improved their loss offset provisions (e.g., by extending the tax loss carryback rules) and reduced business tax rates. To support employment, many countries have paid wage subsidies and introduced or increased short-term work schedules to safeguard jobs. In addition, some countries have enhanced and/or extended eligibility for sick-pay, enhanced tax refunds, and implemented special tax deductions, tax exemptions, tax waivers, and social security contribution waivers.

In addition to avoiding insolvencies and supporting employment during the crisis, many countries have taken measures to overcome the economic crisis. To support investments, some countries have introduced accelerated and bonus depreciations, increased tax incentives for research and development, reduced corporate income tax rates, reduced firms' cost of financing by decreasing withholding taxes on interest or dividend payments, or provided tax credits and tax rebates.

To promote consumption, some countries have used (or are still using) direct cash transfers for households (including vouchers). For example, Denmark provided a one-time check of DKK 1,000 (EUR 135) to people on public transfers, including pensioners and students; U.S. residents with a work eligible social security number and not dependent on another taxpayer are eligible for a $\$ 1,200(\$ 2,400$ joint return) rebate and an additional $\$ 500$ 
per child under age 17; and German citizens receive a bonus of EUR 300 per child. ${ }^{3}$ In addition, to enhance household cash flow and thus support consumption, many countries provide enhanced or extended eligibility for unemployment benefits. For example, the US federal government provided $\$ 600$ a week in supplemental unemployment benefits from the end of March to the beginning of August, 2020. This payment was in addition to what unemployed persons received under the state-based unemployment system. Moreover, 18 countries have reduced their VAT-rates to encourage consumption, either by reducing the rate for specific services and goods (e.g., for certain cultural and tourist services in Norway, electronic publications in the United Kingdom, or restaurant and catering services in Austria, Belgium, and Bulgaria), or by reducing the rate for all goods and services (e.g., in Cyprus, Jamaica, Germany, Kenya). In addition, some countries are using tax waivers and tax credits to encourage specific consumption. In Italy, for example, people receive tax credits of up to $110 \%$ for restructuring of domestic buildings, and households with income lower than EUR 40,000 receive tourist vouchers that take the form of a tax credit between EUR 150 - 500 . Both tax credits can be transferred to hotels, construction companies as well as financial intermediaries. Other countries have withdrawn their tourism tax to stimulate that sector (e.g., Cayman Island, Malaysia).

\footnotetext{
${ }^{3}$ For a discussion of the advantages and disadvantages of providing stimulation payments through the tax system, see Hafiz, Oei, Ring, and Shnitser (2020). The authors emphasize that the tax system already has the information and the infrastructure necessary to deliver payments quickly.
} 


\section{Table 1: Tax policy measures in response to Covid-19 crisis}

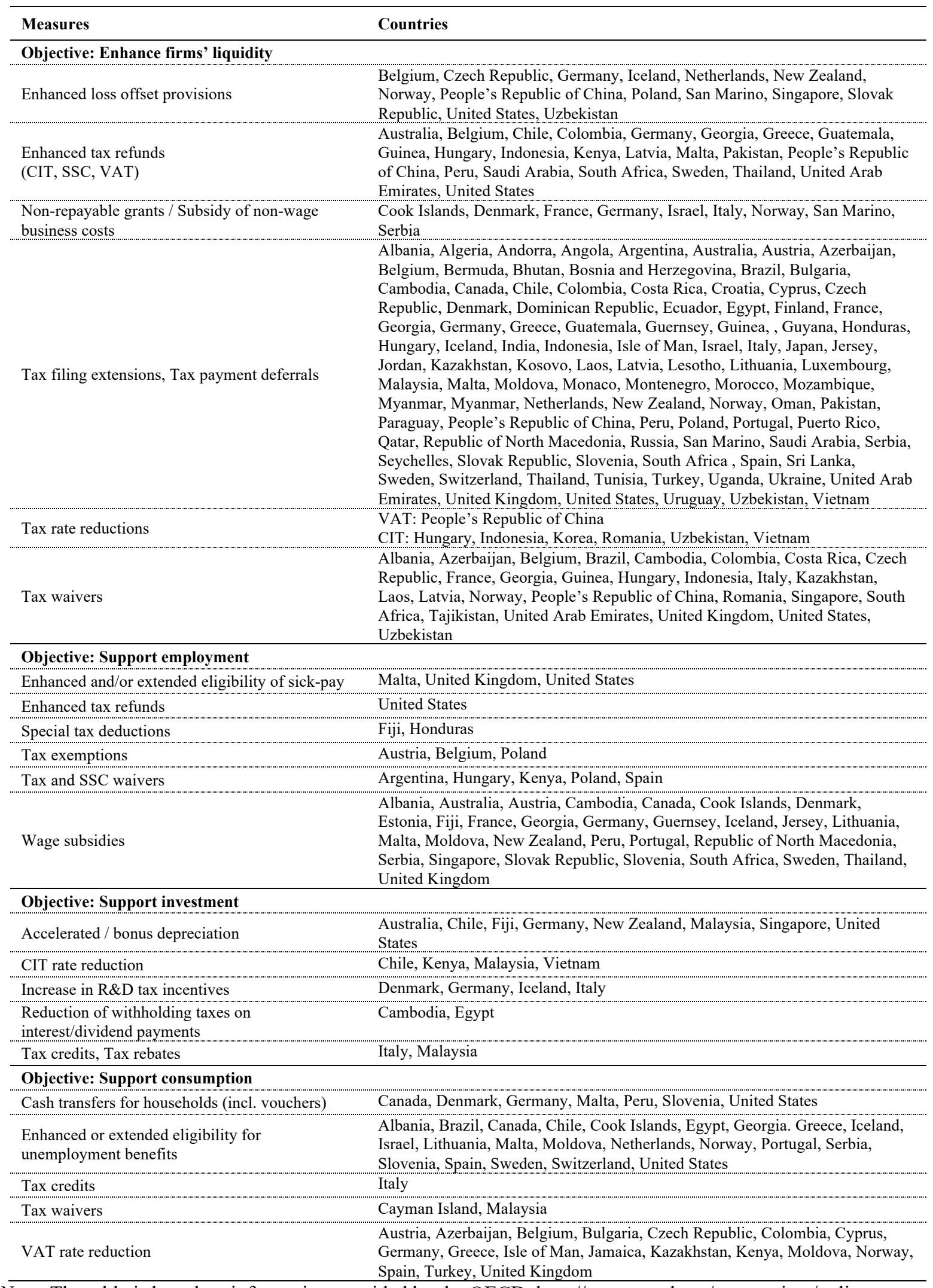

Note: The table is based on information provided by the OECD, http://www.oecd.org/coronavirus/policyresponses/tax-administration-responses-to-covid-19-measures-taken-to-support-taxpayers-adc84188/ (update 29/06/2020). Many countries are providing loans to businesses at (typically) reduced interest rates, providing loan guarantees, etc. These measures have not been included in the table. CIT means corporate income tax, SSC social security contributions, and VAT value added tax. 


\section{$3 \quad$ Perception and effectiveness of tax policy measures}

With the rise of behavioral economics in the previous few decades, tax researchers have intensified their study of psychological effects on economic decisions. This line of research identifies various decision biases and drivers of behavior that may affect policy measures to safeguard health and the economy, by impacting (both positively and negatively) the effectiveness of tax policy instruments. In sum, the perception of economic stimuli and tax incentives and their effectiveness depends on characteristics of decision makers, the properties of the tax incentive, and the specificity of the general decision environment (Blaufus, Chirvi, Huber, Ralf Maiterth, \& Sureth-Sloane, 2020).

Before reviewing research with respect to the policy objectives of promoting consumption and investment in the light of the SARS-CoV-2 pandemic, we summarize key behavioral determinants that governments would do well to consider when choosing between different tax policy measures. As we will repeatedly refer to these determinants in the following subsections, we will first provide a general description. In particular, we emphasize the relevance of salience, complexity, framing, and timing of tax policy measures.

a) Salience: People are more likely to change their behavior in response to salient tax incentives, i.e., incentives that are highly visible. The effect of tax salience on behavioral responses has been demonstrated in several studies (Blumkin, Ruffle, \& Ganun, 2012; Cabral \& Hoxby, 2012; Chetty, Looney, \& Kroft, 2009; Finkelstein, 2009; Goldin, 2012; Sausgruber \& Tyran, 2005; Taubinsky \& Rees-Jones, 2018; Weber \& Schram, 2017). Thus, tax incentives must be salient and perceived as relevant by the addressed recipients.

b) Complexity: Prior research shows that tax incentives are less effective if they are overly complex (Blaufus \& Ortlieb, 2009; Boylan \& Frischmann, 2006; Rupert, Single, \& Wright, 2003; Rupert \& Wright, 1998) or if the decision environment is highly complex (Abeler \& Jäger, 2015). Complexity hides benefits at least for taxpayers with low financial knowledge and literacy (e.g., Chetty, Friedman, Leth-Petersen, Nielsen, \& Olsen, 2014). Thus, if governments aim to shape the behavior of people who have poor tax knowledge, tax incentives must be salient and designed to be as simple as possible.

c) Framing: Changing the framing of tax incentives affects behavioral responses.

Empirical insights suggest that the label "tax" itself may have negative connotations for tax averse individuals and that changing the label of a tax affects its perceived and 
evaluated burden (e.g., Blaufus \& Möhlmann, 2014; Hundsdoerfer, Sielaff, Blaufus, Kiesewetter, \& Weimann, 2013; Kessler \& Norton, 2016). Moreover, according to prospect theory (Kahneman \& Tversky, 1979), it matters whether tax reductions are framed as gains or forgone losses (e.g., Epley, Mak, \& Idson, 2006; Lozza, Carrera, \& Bosio, 2010).

d) Timing: The timing of tax incentives influences tax perceptions (Chambers \& Spencer, 2008; Falsetta, Rupert, \& Wright, 2013) when subjects use mental accounts (Thaler, 1990) or hold prospect theoretical utility functions. For example, small and recurrent (larger lump-sum) tax refunds will be assigned to the mental account "current income" (“asset account") and thus consumed (saved).

\subsection{Effectiveness of tax policy measures to stimulate consumption}

Regarding policy objectives to stimulate consumption, Epley et al. (2006) provide experimental evidence that participants are willing to spend more if a tax reduction is framed as a bonus (gain) instead as a tax rebate (foregone loss). Similarly, a survey by Lozza et al. (2010) found that tax reductions framed as an increase in monthly income (gain) lead to more spending than if they are framed as a reduction in the monthly tax burden (loss reduction). This is in line with the principle of loss aversion, i.e., subjects attach a higher value to the loss reduction setting, and thus will save more and spend less in this setting. Hence, if governments aim to stimulate consumption, behavioral insights suggest that framing tax reductions as a gain might be more successful than framing as a loss reduction. Accordingly, the tax rebate to U.S. taxpayers is framed as "Economic Impact Payment" and not as a rebate; and Germany's taxpayers received a "Corona child bonus" instead of a rebate. By contrast, Singapore's tax administration uses the traditional "rebate frame". Concerning the effectiveness of the temporary VAT reductions, that are used in many countries, framing also matters. Due to the temporary nature of the VAT reductions, people first perceive a price reduction (gain), and subsequently, when the VAT reduction period expires and the reference point has shifted to the reduced tax rate, a price increase (a loss). If people are loss-averse, the price increase will affect their utility more than the price decrease. If the tax was, however, not reduced, but instead a bonus of equal size was offered, and the bonus would later be 
withdrawn, from an economic-psychological perspective, consumers would experience a forgone gain, whereas the tax rate increase would be perceived as a loss.

Moreover, spending behavior may be affected by the way a tax cut is delivered. Chambers and Spencer (2008) showed that the proportion spent of tax refunds administered as one lump-sum is less than tax refunds of the same amount refunded monthly through reduced income tax withholding. From this perspective, it is useful that the German child bonus is not paid out as a one-time payment but in two installments. By contrast, the US economic impact payments were paid out at once suggesting that many individuals will use the payment for savings or repaying debts instead of consuming the money. ${ }^{4}$ One explanation for this refers to mental accounting. Inflows in the "current income" account would be used primarily for consumption, whereas inflows in the "asset" mental account would primarily be used for savings (Thaler, 1990). Since the monthly withholding tax reductions are more likely to be allocated to the current income account, the use for consumption purposes should be higher thereafter than for the lump-sum payment, which would be more likely to be allocated to the asset account. However, a one-time payment could be more salient, and thus, might affect short-run responses more strongly than small changes to the withholding tax. Sahm, Shapiro, and Slemrod (2012) provide evidence to support this speculation: their U.S. survey data indicate that the reduction in monthly withholding tax in 2009 increased spending only by $13 \%$ compared to a $25 \%$ increase from the one-time payment in 2008 . Sahm et al. (2012) found two additional behavioral determinants that can influence the effectiveness of a tax stimulus. First, since salience of a stimulus is relevant, whether the payment is received as a check or as an electronic funds transfer might be important; that is, while one could be passive about an electronic funds transfer, one has to take active notice of a check. The German child bonus, for example, was delivered through direct deposit. By contrast, the US economic impact payments were either delivered through direct deposit, paper checks or debit cards. Second, the level of publicity around the tax incentive matters. Publicity can be achieved through government marketing campaigns, but also through accompanying promotional activities by companies. For example, Kan, Peng, and Wang (2017) found that

\footnotetext{
${ }^{4}$ First analyses of the effect of the US economic impact payments on consumption are provided by Baker, Farrokhnia, Meyer, Pagel, and Yannelis (2020) as well as Coibion, Gorodnichenko, and Weber (2020).
} 
vendors' discounts for a voucher program significantly increased the effectiveness of this policy tool.

With respect to the temporary VAT reductions for all goods and services to encourage consumption (e.g., in Cyprus, Jamaica, Germany, Kenya, see also Table 1), there are further properties that might limit the effectiveness of such measures. ${ }^{5}$ First, research shows that consumption taxes not included in the price but instead added at the register are ignored or underweighted due to lower salience (Chetty et al., 2009; Goldin \& Homonoff, 2013; Taubinsky \& Rees-Jones, 2018). Thus, the effectiveness of a VAT reduction is higher if taxinclusive prices are displayed. However, we observe anecdotally that many local shops only passed on the reduction at the till, and left their shelf prices unchanged. In order to increase the salience of the tax reduction, appropriate marketing campaigns are therefore required. Second, rational inattention phenomena (e.g., Caplin, Csaba, Leahy, \& Nov, 2020) as well as psychological theories of thresholds in price perception (e.g., Lambert, 1978) suggest that small differences sometimes may not change consumption behavior at all, due to a lack of notable differences. For example, it seems unlikely that consumers would buy a new car because the price has dropped from EUR 29,750 to EUR 29,000 due to a reduced VAT rate from $19 \%$ to $16 \%$, as was the case in Germany. Third, it is unclear if and to what extent firms will decrease their prices due to the VAT reduction (e.g., Benzarti \& Carloni, 2019; Kosonen, 2015). Moreover, some papers indicate an asymmetric incidence of VAT changes. For example, Benzarti, Carloni, Harju, and Kosonen (2017) found that prices respond twice as strongly to VAT increases compared with VAT decreases (see also Politi \& Mattos, 2011), reflecting evidence from prospect theory that predicts losses loom much larger than gains.

\subsection{Effectiveness of tax policy measures to stimulate investments}

Regarding the policy objective of supporting investments, prior behavioral tax research shows that the form of the tax subsidy matters for the effectiveness of tax policy measures. Managers of large corporations may focus on financial accounting numbers rather than present value effects of tax incentives because accounting measures are more salient. Graham, Hanlon, Shevlin, and Shroff (2017) report that many corporate managers use the effective tax rate (ETR) instead of the marginal tax rate (MTR) for investment decisions. In this case,

5 Related to a temporary VAT cut by 2.5 percentage points in the U.K. during the financial crisis in 2008/2009, Crossley, Low, and Sleeman (2014) find that the cut raised the volume of retail sales by around $1 \%$. 
accelerated or bonus depreciations (used in countries such as Australia, Germany, New Zealand, and the United States) are not effective in increasing investment activity because they do not affect the ETR. ${ }^{6}$ By contrast, tax credits or grants (used, for example, in Italy) affect accounting numbers such as the ETR, and are therefore more effective for firms that use accounting-based ratios for decision making. In addition, results from Edgerton (2010) indicate that the effectiveness of accelerated depreciations is positively associated with firms' cash flows, suggesting that this kind of tax incentive has the smallest impact on investment during downturns when cash flows are lower. ${ }^{7}$ Furthermore, prior research proposes that tax base changes are generally less weighted than tax rate changes, due to the higher salience and availability of tax rate information (Amberger, Eberhartinger, \& Kasper, 2016; Blaufus, Bob, Hundsdoerfer, Kiesewetter, \& Weimann, 2013). Thus, the corporate income tax rate reductions that are used in countries such as Chile, Kenya, Malaysia, and Vietnam might be more effective than tax base reductions via accelerated depreciations. Blaufus and Milde (in press) have also found that the form of the tax subsidy matters, with matching contributions more effective than tax refunds. Despite the potential positive effect of government matching contributions, we are not aware of any country that has so far used this policy tool during the crisis.

With respect to the complexity of investment incentives, prior research reveals that the take-up of incentives depends on firms' tax literacy. Cui, Hicks, and Xing (2019) find that $80 \%$ of Chinese firms with eligible investment fail to claim the tax benefits from accelerated depreciations and take-up decisions depend on tax sophistication. ${ }^{8}$ Similarly, Zwick (in press) finds that only $37 \%$ of US corporations that could benefit from loss carryback make use of this facility, and that the usage depends both on the use of a paid preparer and the sophistication of the paid preparer. Thus, the complexity of tax rules could significantly limit the effectiveness of investment stimuli. This is important because both instruments, accelerated depreciations and extended loss carryback rules, have been used by a number of countries to stimulate economic recovery (see Table 1). It can be assumed that these instruments are only effective for companies that make use of sophisticated tax advice.

6 This might also explain the observation by Zwick and Mahon (2017) that small firms respond more to depreciation incentives than big firms.

7 Moreover, there is some evidence that bonus depreciations significantly lower the quality of investment (Eichfelder, Jacob, \& Schneider, 2020).

8 Low take-up rates are also reported for the United States (Kitchen \& Knittel, 2016). 
Further behavioral research regarding the effect of loss offset rules suggests that subjects overestimate the effect of tax loss offsets, resulting in more risk-taking in investment choices (Fochmann, Kiesewetter, \& Sadrieh, 2012a, 2012b). Similarly, Bethmann, Jacob, and Müller (2018) find that enhancing tax loss carryback rules increases investments, with the positive response driven primarily by firms that are prone to engaging in risky overinvestments. In addition, loss carryback rules are only beneficial for firms with positive taxable income in the past years, so that this measure discriminates against younger firms or more innovative firms that have not yet achieved taxable profits. Risk-taking is also affected by the timing of taxation. Falsetta et al. (2013) show that taxpayers invest more (less) in a riskier asset when a tax decrease (increase) is implemented gradually rather than in one go. In a similar vein, Falsetta and Tuttle (2011) find that subjects entitled to claim a tax refund take significantly less investment risk than those who have to pay an additional tax. Finally, behavioral tax research has demonstrated the importance of emotions in investment responses to tax incentives. Fochmann, Hemmerich, and Kiesewetter (2016) show that the more pleasant and less exciting a tax treatment ${ }^{9}$ is perceived to be, the greater is the risky investment. Fochmann, Hewig, Kiesewetter, and Schüßler (2017) also provide evidence that investors do not change their risk-taking behavior as a direct consequence of changing tax rules, yet they do react in response to the affective perception of these different tax rules.

\footnotetext{
${ }^{9}$ A service-oriented tax authority that treats taxpayers with respect and sympathy, provides transparency, processes fast and reduces uncertainty about vague tax outcomes might lead taxpayers to perceive a pleasant and less exciting tax treatment. Please note that Fochmann, Hemmerich, and Kiesewetter (2016) used an abstract setting in which they asked their participants to rate a tax situation with respect to valence ("How pleasant do you perceive the situation?") and arousal ("How excited are you to be in the situation?").
} 


\section{Acceptance of tax measures and compliance}

\subsection{Trust, power, and tax compliance}

The perceived effectiveness of the described tax policy measures to combat the crisis and to enhance economic recovery will affect peoples' trust in the government, and greater trust will shape compliance with the policy measures (Devine, Gaskell, Jennings, \& Stoker, 2020; van Bavel et al., 2020). Trust is a key determinant of peoples' tax compliance according to the Slippery Slope Framework (Kirchler, Hoelzl, \& Wahl, 2008). ${ }^{10}$ This framework proposes that the interaction climate between taxpayers and the authorities shapes the willingness to cooperate. In a synergistic climate, characterized by high trust in the authorities who act with high legitimization and professionalism, taxpayers are willing to cooperate voluntarily. On the other hand, in an antagonistic climate, characterized by low trust, poor legitimization, and questionable professionalism, taxpayers refuse to cooperate, unless compliance with the law is enforced. Thus, taxpayers' compliance depends on the power of the authority and trust in the authority. Both dimensions moderate each other and determine the level of compliance. Whereas an authority with a higher level of power (determined by factors such as frequent and effective audits, high detection probability, and severe fines) affects enforced tax compliance, trust in authority (determined by factors such as fair procedures and fair distribution of tax burdens, favorable attitudes towards the government, taxation and the authorities, and social norms which define compliance as the prevalent behavior) particularly affects voluntary compliance.

Notably, many measures taken by governments to safeguard health and stimulate the economy affect either (or both) perceived power or trust, and consequently affect tax compliance. Although both the dimensions of power and trust are altered by the pandemic and various tax measures taken, we argue that - above all - trust in the authority might be affected by these measures, through various channels.

Impact on trust in the authority. Citizens' acceptance and evaluation of government in combating negative consequences of the pandemic affect compliance (Devine et al., 2020). Various measures affect trust in the authority and subsequently shape compliance behavior. Gärling, Kirchler, Lewis, and van Raaij (2010) list seven criteria that underlie trust in

\footnotetext{
${ }^{10}$ A similar approach is provided by Alm (2012) who emphasize the role of enforcement, services, and trust as "paradigms" for tax administrations.
} 
financial institutions that are relevant with regard to tax authorities and are therefore important when building and maintaining trust:

- $\quad$ Authorities need to be competent, and must act professionally and objectively.

- The integrity of authorities is crucial. Integrity means that all citizens are treated according to ethical principles; i.e. are treated fairly and are not fundamentally considered to be lawbreakers until the opposite is established. In addition, authorities must behave authentically, demonstrating sincere commitment to the welfare of their citizens.

- The actions of authorities must be transparent: rules and procedures are clearly and accurately communicated, ensuring that rules and procedures are correctly understood by the recipients.

- $\quad$ Authorities must act with benevolence, meaning that the perspective of the citizens is taken into account and their interests are considered.

- $\quad$ Authorities must demonstrate the values and norms that define their behavior align with those of their constituents (e.g., congruence). Congruence is a prerequisite for the identification of citizens with the state.

- Stability of government institutions is essential. Authorities must be able to do their work in the long term in the service of the citizens.

- Finally, a positive image of the authorities is important. Reputation, especially positive citizens' attitudes towards the authorities and their activities, is essential for building and maintaining trust.

Citizens' trust and compliance increases in line with perceptions on the appropriateness and fairness of governmental measures. Perceived effectiveness of tax measures, procedural justice, distributive justice, and retributive justice are most important to build and maintain trust, and consequently to ensure willingness to cooperate.

Impact on power of the authority. Besides trust, the power of authorities is key: professionality and efficient controls and sanctions in the event of illegal activity are crucial for enforcing compliance. In terms of power, it is important that power is perceived as legitimate and necessary, that the authorities are ready and able to efficiently and effectively detect rule-breakers, and that fines are appropriate in the event of misuse of public funds. Besides legitimate power, coercive power can strengthen voluntary cooperation. However, coercive power increases voluntary compliance only if citizens perceive that the authorities 
appropriately target non-compliant citizens with harsh measures and also that the authorities are willing and able to protect cooperative citizens against exploitation by free riders. Effective audits and severe punishments can strengthen the trust in authorities held by those who voluntarily adhere to the rules, if controls are clearly aimed at free-riders and not imposed randomly. The perception of poorly targeted controls undermines trust as they are perceived as a signal of distrust on the part of the authorities with respect to citizens, which results in distrust on the part of citizens in the state.

The consequences of the pandemic on the economy, combined with the financial stimuli and the tax measures to safeguard the economy, will have a devastating impact on all governments' current and future budgets. Governments will face decisions about increasing taxes in the future and/or reducing expenditures. While raising taxes is usually perceived as a highly unpopular strategy that might fuel non-compliance, a reduction in government expenditures will likely result in less public goods and affect the power of authorities to carry out audits and other compliance initiatives. If the probability of audits and other compliance techniques touches decline and tax staff need to engage in new and unfamiliar activities, aggressive tax avoidance and evasion are likely to increase. Current audit capacity restrictions (as described below, see "Detection probability") will reduce the probability of detecting tax fraud, thus shrinking the power of the authority. Remarkably, weak power might covary with lower enforced compliance and lead to lower trust in the authorities' capacity to protect cooperative citizens from being exploited by free riders, which will eventually lead to lower voluntary compliance.

\subsection{Policy measures and determinants of tax compliance}

In the following, we speculate on how the Corona crisis and policy measures to combat this crisis might impact different determinants of tax behavior and finally influence tax compliance. We distinguish between three dimensions: 1) trust in authority, 2) power of authority, and 3) individual traits and situational characteristics. Table 2 provides an overview and highlights the influence on tax compliance. 


\section{Trust in the authority}

Perceived effectiveness of tax measures. In section 3, we discussed a variety of behavioral responses to tax measures and their impacts on perceived effectiveness. If individuals accept tax measures and feel confident that they are appropriate in combating the negative consequences of the Corona crisis, the government will be perceived as acting professionally, and trust in the government will increase. In contrast, if they perceive tax measures as too costly and doubt that they are effective, trust will decrease. As a result, a lower (higher) trust in authority will reduce (increase) willingness to pay taxes, and, consequently, the level of tax compliance will decrease (increase) (Kirchler et al., 2008). Tax measures and their perceived effectiveness will also affect one's belief about one's own income situation in the future. If current measures heavily increase public debt, higher taxes or lower transfers might lead to future income losses. Moreover, ineffective measures might amplify the risk of a long-lasting economic crisis with negative consequences such as consumption shocks, higher unemployment, and lost tax revenues. Individuals experiencing the resulting income loss might change their tax compliance level. On the one hand, higher taxes or an income shift might change compliance directly (Allingham \& Sandmo, 1972). On the other hand, income losses might change compliance indirectly by changing the willingness to take risk (see below).

Procedural justice. Individuals require fair treatment when they have to provide resources for the society, such as paying taxes. The processes of paying taxes, including declaration of tax returns, audits, collection, and interactions with tax authorities, should be fair, transparent and simple. Taxpayers not only desire fair procedures because they believe that these would lead to fair distributions (e.g., Thibaut \& Walker, 1975), but also because the opportunity to express one's own opinion carries value in itself and contributes to perceived fairness (e.g., Tyler, 1987). There is substantial evidence that tax compliance and tax morale are affected by the way the tax authority treats taxpayers (see, e.g., Feld \& Frey, 2002; Torgler, Demir, Macintyre, \& Schaffner, 2008). Consequently, procedural justice is seen as an important determinant of tax compliance and literature provides conclusive evidence that individuals who perceive they have been unfairly treated will exhibit lower tax compliance (Alm, 2012, 2019; Beers, LoPresti, \& San Juan, 2012; Hartner, Rechberger, Kirchler, \& Schabmann, 2008; Hofmann, Hoelzl, \& Kirchler, 2008). During the pandemic, the work of authorities was limited along with most other parts of the economy. As a consequence, 
taxpayers' opportunities to interact (at least personally) with the tax authority were limited, potentially resulting in a perception that procedures are less transparent due to the adjustments and limitations of work. These factors in combination might produce a decrease in tax compliance due to a lower level of perceived procedural justice. Furthermore, tax measures adopted by the government likely imposed annoying bureaucratic hurdles on individuals, which also reduced perceived procedural justice.

Distributive justice. Tax measures will affect the exchange of benefits and costs and perceptions of this exchange's fairness. There is little doubt that some members of society do not equally benefit from tax measures or equally share the burden of the crisis costs (e.g., Adams-Prassl, Boneva, Golin, \& Rauh, 2020). As a result, the principles of horizontal and vertical fairness/equity are violated, and it has been demonstrated that reduced fairness (due to lower level of perceived distributive justice) will reduce tax compliance (Hofmann et al., 2008). Importantly, the fairness perception might be driven by whether an individual is directly affected by the costs (e.g., income losses) or by the benefits (e.g., transfers), and also by whether her/his peer group (e.g., the same industry sector) is affected to the same extent. Thus, fairness concerns might be relevant, for example, when industry sectors are treated equally (e.g., by a general transfer program), even though they are affected differently by the Corona crisis (e.g., restaurants, theatre, and event industries are most affected). These concerns might be even stronger if an individual does not benefit from a measure whereas other individuals from the same industry sector do.

Retributive justice. In many countries, we observe that tax measures are undermined by fraudulent behavior. For example, individuals may set up shell companies to participate in subsidies offered by the government, thereby dishonestly obtaining funds meant to help avoid insolvencies. If fraudulent behavior or freeriding is not caught by authorities or is not adequately penalized, the strength of retributive justice like audits and punishments might be reduced significantly. The consequence may be a general drop in tax compliance across society due to a lower level of retributive justice (Hofmann et al., 2008).

\section{Power of the authority}

Detection probability. The Corona crisis has confronted tax authorities with additional restrictions on audit capacity. For example, administrative employees may be in their home offices and are therefore not able to run audits, or they may have been withdrawn and 
deployed in other areas (e.g., handling the administrative process for Corona transfers). As a consequence, there is a reduced probability that tax evasion will be detected. If taxpayers anticipate the drop of audit/detection probability, it is possible that they will lower their tax compliance level (Allingham \& Sandmo, 1972). Additionally, spillover effects of other enforcements might occur. If, for example, failing to wearing a mask in a public setting is neither checked nor penalized, individuals might think that the authority will also not audit tax returns; if specific rules during the pandemic (e.g., lockdown rules) are enforced, the perceived audit probability of tax returns might increase. Also, the use of stimulus delivery mechanisms that create an electronic trail (e.g., third-party information reporting) might well increase individuals' perceptions of audit probabilities (Adhikari, Alm, Collins, Sebastiani, \& Wilking, 2020; Adhikari, Alm, \& Harris, 2020).

\section{Individual traits and situational characteristics}

The tax compliance literature has identified several drivers of tax compliance on the individual level, two of which are the general attitude towards taxes (often referred to as tax morale) and the individual risk attitude. The literature provides robust evidence that individuals holding positive attitudes towards taxes - i.e., those with a higher tax morale exhibit higher tax compliance (Alm, 2019; Kirchler, 2007; Lewis, 1982; Torgler, 2002, 2007). As tax evasion carries the hazard of being penalized with a certain probability, the tradeoff between obtaining a certain outcome when being compliant, and achieving potentially higher outcomes with the risk of eventually facing a fine when being non-compliant, depends also on a decision maker's willingness to take risk (Allingham \& Sandmo, 1972; Srinivasan, 1973). In particular, higher risk inclination is associated with lower compliance.

Besides these two drivers, perceived justice as a basis of trust, the capacity to audit effectively as a basis of power and social norms along with personal and situational characteristics (e.g., moral balancing, experiencing unexpected events, and emotions) shape tax compliance. Moreover, framing effects (e.g., perception of gains, losses, forgone gains or losses) also affect tax decisions. In the following, we discuss how the Corona crisis might alter tax compliance by affecting these determinants of tax behavior.

Moral balancing. Moral balancing theory (Nisan \& Horenczyk, 1990) suggests that individuals take into consideration their self-image over time, aspiring to a moral status at a 
level that they consider satisfactory. ${ }^{11}$ This theory also explains how individuals manage deviations from their individual moral self-image. If morally valuable actions in the past led to a moral status above the threshold, individuals might engage in immoral activities in the present (Merritt, Effron, \& Monin, 2010; Zhong \& Liljenquist, 2006). ${ }^{12}$ Especially in the beginning of the crisis, the majority of individuals behaved in a morally correct manner (e.g., acted in solidarity, accepted individual utility losses when following the hard Corona restrictions such as lockdowns, travel restrictions, and prohibition of family visits.). This moral behavior might trigger a license to cheat when completing the tax return, resulting in lower tax compliance.

Unexpected events. Unexpected but severe events typically influence an individual's willingness to take risks. Unexpected unemployment has been shown to be an important driver of risk aversion (Hetschko \& Preuss, 2019). The resulting poverty may lead to shortsighted and risk averse behavior (e.g., Haushofer \& Fehr, 2014). Similarly, the experience of a negative (and possibly long lasting) economic development may also lead to a lower willingness to take risks. For example, individuals who have experienced low stock-market returns during an economic crisis report a lower willingness to take financial risks and are less willing to participate in the stock market in the future (Malmendier \& Nagel, 2011). Finally, natural disasters also seem to make individuals less willing to take risks (Cameron \& Shah, 2015; Goebel, Krekel, Tiefenbach, \& Ziebarth, 2015), and a lower willingness to take risks is associated with higher tax compliance.

Emotions. Strong emotions are likely in the context of a pandemic, such as uncertainty, fear, anger, and reactance. Fear might arise because individuals are afraid of the possible severe consequences for their health and/or their economic situation. In contrast, anger might be caused by measures to fight the pandemic, which restrict one's own freedom and might be perceived as unnecessarily hard (e.g., lockdown and economic disruption). Importantly, fear and anger have different effects on the willingness to take risks and finally on tax compliance. Whereas fear increases risk aversion (and leads to more tax compliance), anger typically leads

11 Also referred to as the economics cost-benefit-balancing in psychology (Pickhardt \& Prinz, 2014).

12 The opposite is moral cleansing where an individual follows a moral behavior after having engaged in an immoral activity (Sachdeva, Iliev, \& Medin, 2009). 
to more risk seeking behavior (and less tax compliance) (e.g., Hetschko \& Preuss, 2019; Lerner \& Keltner, 2000, 2001; Lerner, Li, Valdesolo, \& Kassam, 2015).

Others' behaviors. The behavior of an individual mainly depends on descriptive norms, which generally refer to a perception of others' behaviors that are based on observation of peers and relevant others with whom the individual identifies. One consequence of this might be conformism; i.e. the phenomenon that individuals change their behavior to match the behavior of others (Bolton, Ockenfels, \& Stauf, 2015; Cialdini \& Goldstein, 2004; Janis, 1972). As a result, the behavior of others might give an individual a "license to cheat". If taxpayers observe others to be less tax compliant - for example due to the points discussed above - they may also be less compliant (Alm, Bloomquist, \& McKee, 2017; Blaufus, Bob, Otto, \& Wolf, 2017; Fochmann, Kocher, Müller, \& Wolf, 2019; Frey \& Torgler, 2007) ${ }^{13}$.

Loss domain. Prospect theory predicts that individuals are risk seeking in the loss domain and risk avoiding in gain situations (Kahneman \& Tversky, 1979; Tversky \& Kahneman, 1991). If individuals have suffered (or expect to suffer) losses due to the Corona crisis (e.g., loss of income through unemployment, salary reduction, higher taxes), they might accept higher risks and consequently exhibit lower compliance levels. Please note that although unexpected events such as unemployment might lead individuals to be less willing to take risks (see above), prospect theory indicates they may be more willing to take risks due to loss of income and override their risk aversion. Losses might not only lead to risk seeking and illegal (evasion) strategies, but also to loss repair by applying legal (avoidance) strategies.

Withholding phenomenon. In contrast to loss repair and risk seeking, an income reduction or loss due to economic contraction might lead taxpayers to expect a tax refund when completing their tax declaration, as they paid too much in advance (or benefit from a loss carryback). The literature on the income tax withholding phenomenon would then suggest that those taxpayers demonstrate higher compliance (Chang \& Schultz, 1990; Elffers \& Hessing, 1997; Engström, Nordblom, Ohlsson, \& Persson, 2015; Jackson \& Hatfield, 2005; Robben, Webley, Elffers, \& Hessing, 1990; Schepanski \& Shearer, 1995). This phenomenon can be explained by the value function of prospect theory (Kahneman \& Tversky, 1979). If

${ }^{13}$ Evidence from public good experiments indicates that around 50 percent of the subjects are conditionally cooperative (Fischbacher, Gächter, \& Fehr, 2001) although cooperation norms vary substantially based on cultural differences (Gächter \& Herrmann, 2009). 
too much money is withheld as prepaid tax (over-withholding), individuals receive a tax refund at the year-end. This tax refund is regarded as a gain if the subject's reference point is the current cash position. Prospect theory predicts individuals will be risk averse in case of a gain frame. Thus, they tend to risk less when confronted with a tax refund and become more tax compliant.

Table 2: Covid-19 crisis, determinants of tax behavior and tax compliance

\begin{tabular}{|c|c|c|}
\hline Dimension & Phenomenon & Effect \\
\hline \multirow{4}{*}{$\begin{array}{l}\text { Trust in } \\
\text { authority }\end{array}$} & $\begin{array}{l}\text { Effectiveness of tax } \\
\text { measures }\end{array}$ & $\begin{array}{l}\text { Tax measures perceived as effective increase tax } \\
\text { compliance. }\end{array}$ \\
\hline & Procedural justice & Fair treatment of taxpayers increases tax \\
\hline & Distributive justice & compliance \\
\hline & Retributive justice & $\begin{array}{l}\text { Well targeted punishment of fraudulent behavior } \\
\text { or free riding lead to perceived retributive justice } \\
\text { which consequently increases compliance }\end{array}$ \\
\hline $\begin{array}{l}\text { Power of } \\
\text { authority }\end{array}$ & Detection probability & $\begin{array}{l}\text { High audit capacity and efficient audits increase } \\
\text { tax compliance }\end{array}$ \\
\hline \multirow{7}{*}{$\begin{array}{l}\text { Individual } \\
\text { traits } \\
\text { and } \\
\text { situational } \\
\text { charac- } \\
\text { teristics }\end{array}$} & Moral balancing & $\begin{array}{l}\text { Moral behavior in the beginning of the crisis } \\
\text { might result in lower tax compliance }\end{array}$ \\
\hline & Unexpected events & $\begin{array}{l}\text { Unexpected severe events, such as natural } \\
\text { disasters or unemployment decrease willingness } \\
\text { to take risks and consequently increase tax } \\
\text { compliance }\end{array}$ \\
\hline & \multirow{2}{*}{ Emotions } & $\begin{array}{l}\text { Fear will decrease willingness to take risks which } \\
\text { increases tax compliance }\end{array}$ \\
\hline & & $\begin{array}{l}\text { Anger will increase willingness to take risks } \\
\text { which lowers tax compliance }\end{array}$ \\
\hline & Others' behavior & $\begin{array}{l}\text { Individuals are guided by the behavior of others; } \\
\text { if others are perceived as compliant compliance } \\
\text { increases }\end{array}$ \\
\hline & Loss domain & $\begin{array}{l}\text { Suffering losses might trigger a higher } \\
\text { willingness to take risks and consequently to } \\
\text { lower tax compliance. }\end{array}$ \\
\hline & Withholding phenomenon & $\begin{array}{l}\text { Expecting a tax refund when completing the tax } \\
\text { declaration increases tax compliance. }\end{array}$ \\
\hline
\end{tabular}




\section{Strategies to maintain citizens' willingness to cooperate}

How can citizens' willingness to comply with the tax law during and after the crisis be maintained? Studies on power and trust and observations of the behavior of authorities and citizens during the crisis allow some conclusions about how to maintain willingness to cooperate during and after the crisis, conclusions that are directly relevant to improving tax compliance in order to provide necessary post-pandemic tax revenues.

In times of crisis, authorities must not stop communicating. Measures taken by the authorities must be transparent and justified, and bureaucratic hurdles must be low. Services need to be provided. The social norm of cooperation should be binding, and control must not be lax with respect to the unjustifiable use of aggressive avoidance and evasion of taxes. When planning and communicating interventions, authorities should also consider possible framing effects. The enormous financial costs and future uncertainties require development of all possible scenarios and respective strategies in order to avoid surprises and to maintain the ability to be responsive. Finally, authorities should be prepared to face distorted recall of past measures and the level of acceptance from the public, so that it would be advisable to keep records about their reasoning and justification.

(1) Communicate, communicate, communicate. The first rule of crisis management is communication. It is important to provide the population with clear information about all behavioral restrictions and economic stimulus measures taken by the government, and especially rights and obligations and access to support. Furthermore, it is vital to communicate new insights around the development of the crisis that will necessitate flexibility and adjustment strategies. Ideally all relevant information can be assessed through one channel. One possibility would be to integrate newsfeeds into Corona-Tracking-Apps. By doing so, citizens would be informed about both new rules and possible threats just in time. As a side effect the acceptance of such apps might also increase.

(2) Justify clearly and transparently. Economic stimulus packages financed by tax money need to be justified and their forecasted effects must be clearly communicated. As far as possible, justification should be based on scientific evidence, and the design of tax incentives should draw on findings from behavioral tax research, as discussed in detail in section 3. The efficient use of tax money, any investments in public goods, and the advantages of public goods for society must be understood and accepted by the public. 
Attitudes towards the behavioral restrictions and financial stimuli measures must be favorable to keep tax morale high. Misinformation and disinformation must be remedied quickly and consistently.

(3) Keep things simple. The obstacles to accessing support and adhering to the rules must be kept as low as possible. This applies both to support and obligations in the extension of deadlines to file tax returns, payment schemes, penalties in case of late filing or payment and other measures taken to cope with financial hardship. Bureaucratic hurdles in getting financial support and tax releases must be kept low. Simple rules reinforce the impression that authorities are acting benevolently, sensitively, and for the benefit of both the individual and society. This leads to perceived procedural justice, which forms the basis of trust.

(4) Provide services. Services are important and must be offered in the required quantity and above all in high quality. Thus, the tax administration must act as a facilitator and provider of services to citizens (Alm \& Torgler, 2011). Professional service requires that public administration employees are clearly informed about the applicable regulations and their implementation. Staff in public institutions must be available for personal interaction with the public and maintain a high "code of ethics". Digital information can support but cannot replace person-to-person communication. In general, no rule can be applied sensibly in all cases: a one-size-fits-all strategy seldom works. Staff must be trained efficiently so that they have legal expertise and can inform citizens according to their motivation and understanding. This requires that citizens are segmented according to their needs and that appropriate services are offered to those critically vulnerable. Thus, employees must be instructed in the flexible application of rules, without violating any fairness principles or being seen to allow fraudulent behavior.

(5) Use controls and penalties. The crisis has brought many self-employed individuals and companies into economic difficulties and caused considerable financial losses. Financial losses weigh heavily and motivate people to take greater risks to repair their position. The perception of deficits in distributive justice could also fuel horizontal distrust. If a neighbor claims support without legal justification, gets an unfair share compared to others, or avoids or evades taxes, this behavior encourages others to emulate that behavior. In order to prevent this undesirable behavior from becoming the norm, controls must be announced and carried out in a targeted manner. Government agencies must not risk losing their authority to ensure compliance with the law. Even so, the crisis may provide a good opportunity to discuss 
alternative methods of penalizing taxpayers. For example, penalties could be suspended for up to two or three years provided that specific criteria are met. This might be seen as a fair procedure among taxpayers and a fair warning to take corrective action for those who are noncompliant. Such a suspension approach encourages a perception that the tax administration cares about solving the taxpayers' non-compliance problems. It also increases the level of information, provides educational possibilities, and generates procedural information, thereby increasing the capacity for cooperation (Ostrom, 2005). However, the necessary criteria require careful selection. There is evidence that incentive contracts can undermine voluntary cooperation by changing the perception of the purpose of the contract (Gneezy \& Rustichini, 2000). Applying agreed criteria will increase the commitment to comply, solving not only the shortfalls in tax payment from the current year but also strengthening the commitment towards compliance in future years. A general and fair agreement will also promote individuals' tax morale because it will be perceived by the taxpayers as respectful and could thus promote long-term compliance. It will also reduce the possibility that taxpayers could engage in mental justification, reinterpretations, and other sorts of strategies to suppress their moral standards in case they fail to comply; this is a strategy to maintain a positive self-image (Shu, Gino, \& Bazerman, 2011). Alternatively, the tax administration could also apply a oneoff strategy of penalty relief, meaning that no penalties are given for shortfall amounts due to false or misleading statements, available only once and under a fixed threshold. Refraining from the imposition of a fine - especially in case of current inability to pay - could be perceived as a generous act that can generate respect among taxpayers and encourage reciprocity. Taxpayers sometimes struggle with the process necessary to make a correct declaration, leading to unintentional errors. The policy may be seen as a sort of "gift", and providing relief to taxpayers sends a signal that they should learn more about the process for future returns. A gift is nothing if not an expression of benevolence, and encourages identification with the giver, in this case the tax administration (Boulding, 1981). However, a lack of punishment or conditional sanctions may reduce the motivation to take immediate care of the procedural problems that led to non-compliance, causing future shortfalls.

(6) Target controls. While perceived legitimate power (audits and punishments in the event of illegal activity) strengthens trust in authority, coercion can be a double-edged sword. If the tax authorities take coercive measures targeting free riders who take advantage of society, then the cooperative majority will be protected from free rider harm. However, if coercive measures are arbitrarily imposed upon anyone or everyone, then they act as a signal 
of general suspicion. Random or poorly targeted audits and disproportionate punishments reduce trust in the authorities and consequently voluntary cooperation of the citizens.

(7) Reward tax compliance. When coping with a crisis, an additional strategy might be found in the use of a carrot rather than just a stick. Instead of raising the relative cost of not paying taxes, the reward increases the benefits of paying taxes (Feld, Frey, \& Torgler, 2006). The advantage of using rewards to motivate desired behavior lies in its perception as a supportive policy (see, e.g., Nuttin \& Greenwald, 1968) that can encourage tax morale. A theoretical study by Falkinger and Walther (1991) shows that a mixed penalty-reward system improves the taxpayer's position and also does not lower the tax revenues of the government. Introducing rewards, together with an increase in the penalty, constitutes a welfare improvement. Some experimental results also indicate that rewards improve compliance (Alm, Jackson, \& McKee, 1992; Torgler, 2003), and also that there are different ways of rewarding compliant taxpayers (Koessler, Torgler, Feld, \& Frey, 2019). One inexpensive option for the tax office is to issue compliance certificates for firms (Feld et al., 2006). Such a certificate demonstrates that the firm is a "good" taxpayer, and this recognition could potentially affect a firm's reputation, image, and share prices. A “good corporate citizen" may receive more favorable conditions on the capital market, and customers' trust in the firm's products may increase. However, the use of a system of rewards depends strongly on the tax administration's assessment of a good taxpayer. As Feld et al. (2006) point out, the tax administration's reputation may suffer if notorious tax evaders manage to go undetected, and consequently are rewarded by mistake. A lack of adequate assessment therefore reduces the strength of a system of rewards. A simple reward approach is the introduction of a discount for on-time lodgments. There is substantial evidence that monetary incentives are powerful tools for motivating people (Kamenica, 2012). However, the application of a discount for ontime lodgment and payment is likely to be discounted by the taxpayers as a "claim"; that is, the discount may become a basic expectation rather than a sign of gratitude. This would reduce the positive influence on tax compliance, and may even reduce taxpayers' internal satisfaction derived from compliance ("warm glow effect") (Rode, Gómez-Baggethun, \& Krause, 2015). Alternatively, the tax administration could praise positive changes made by the taxpayers. In general, an authority that praises individuals will appear more concerned about taxpayers (Smith \& Stalans, 1991). 
(8) Establish cooperation as a socially binding norm. Behavioral economics has consistently demonstrated that many individuals are motivated by social norms and intrinsic motivation and that individuals are capable of learning and updating social norms (Ostrom, 2005). Sharing the message that the majority is willing to cooperate and does not abuse support services (e.g., short-time work, tax relief, and public benefits) is effective because the cooperation is defined as the social norm, which serves as a guideline for behavior. As the massive debt incurred to fund stimulus measures is likely to burden future generations, one should also consider to update and recall social norms by communicating the importance of tax compliance on the welfare of future generations. In addition to establishing and communicating social norms for cooperative behavior, measures must be taken to strengthen the identification of citizens and residents with the cooperative society. Here, one possibility would be to explicitly acknowledge cooperative behavior to increase visibility, just as some selected firefighters are typically honored after large fires.

(9) Recognize that framing affects choices. The ways by which policies are communicated is crucial. For example, prospect theory demonstrates that losses outweigh gains, and this should be taken into account when communicating that measures are being introduced or revoked.

To illustrate some considerations, suppose that the rate of VAT is lowered for some time to stimulate consumption. However, how complex is the actual implementation in the retail sector, and - even if the reduction is passed on to consumers - will consumers perceive the scheduled reduction in the tax rate and will they find it fair? To be effective, a change must be above the perception threshold. If the VAT rate is $19 \%$ as in Germany, a halving of the tax rate would certainly be experienced as reduction of prices. However, would consumers also see and respond to a reduction from $19 \%$ to $16 \%$ as implemented in Germany? Perhaps people from poorer classes would experience relief, but those who are wealthy might not notice the price change. It is also important to consider what can happen if the reduction is withdrawn. The reduction from $19 \%$ to $16 \%$ would probably be perceived by many as a gain and might well affect consumers. The $16 \%$ tax rate would become the new reference point. If - as announced - the VAT is raised again to the previous $19 \%$, this appears as a loss, and goods will be experienced as more expensive than they were before the tax rate reduction because losses have a greater impact than gains. Therefore, returning to the previous tax rate would subjectively not be perceived as such. If the tax was, however, not reduced from 19\% 
to $16 \%$, but remained at $19 \%$ and a bonus of equal size was offered, objectively the reduction would be equal. If the VAT is set at $19 \%$ and the bonus is later withdrawn, from an economicpsychological perspective, consumers would experience a forgone gain, whereas the increase from $16 \%$ to $19 \%$ represents a loss. Behavioral consequences would differ across these different scenarios.

Besides affecting consumer behavior, the temporary reduction of VAT and reduction of prices for consumers could cause administrative problems to small and medium enterprises but would be easily administrable by large firms. If small and medium enterprises are not able to cope with the administrative task in the short run, while large firms encounter little problems and offer goods at reduced prices, consumers comparing prices might be tempted to buy from the large businesses rather the more expensive small and medium firms. This would cause disadvantages between competing suppliers, and further affect those already feeling the worst of the economic effects.

(10) Plan for the future. The large shock to the economy, the extensive economic stimulus packages, state guarantees, and reduced tax revenue have caused enormous fiscal deficits. Moreover, the future evolution of the health crisis is uncertain, making further lockdowns possible. It seems obvious that governments around the world will need to deal with uncertainties and fiscal pressures for many years in the future. Governments need to be aware of possible fiscal risks, be flexible, and be ready to adjust their strategies to yet unforeseeable developments. They need to beware of surprises. Thus, it is of paramount importance to plan for all possible future scenarios and intervention strategies and to communicate the scenarios. The public in general and markets in particular must understand the various possible scenarios and the necessity of applying strategies in a highly flexible manner, given the high degree of uncertainty. Rather than blaming the authorities as weak, being prepared for all eventualities must be conceived as a strength.

(11) Beware of hindsight bias. Once the health crisis has been overcome, economic hardship will continue to hurt society in general and specific sectors in particular, posing severe challenges for fiscal systems. In retrospect, it may be difficult to remember that these actions were taken because of the goal of putting people's health above everything, thereby requiring massive government expenditures to safeguard jobs and health and leading to enormous economic dislocations. Experiences will fade and memories will be re-constructed on the basis of current experiences and motives. In retrospect, we might perceive the austerity 
measures as inappropriately high, we might complain about insolvent companies and unemployed workers, and we might well blame governments for the excessive economic sacrifices that have led to higher taxes. In order to ensure acceptance of future financial sacrifices and solidarity in society, it is not only essential to plan and communicate interventions by the government, but also to publish them and to keep record of measures, programs, and justifications taken during the crises, when uncertainty was at its highest levels. A centralized information platform might be useful, in which all actions during the crisis are listed and accompanied by clear and concise justifications that include also descriptions of the level of uncertainty, policy makers were facing when decisions had to be taken.

\section{Conclusion}

Governmental restrictions and economic stimulus measures in response to the pandemic are likely affecting citizens' tax compliance behavior. We reflect the possible impact of tax policy measures during the pandemic on future tax compliance and retain it advisable to derive insights from a behavioral economic perspective to ensure future tax compliance. Analyses of economic stimuli measures and taking stock of theoretical elaborations on the interplay between legitimate and coercive power of the administration and citizens' trust in the government, we conclude that the first rule of crisis management is communication and provision of clear information. Economic stimulus packages must be justified and transparent. Access to support must be simple and services must be provided by the tax administration. In order to prevent undesired behavior, controls and penalties in case of norm violation are required. Controls, however, need to be well targeted to signal protection of compliant citizens from exploitation by free riders. Tax compliance should be rewarded and communicated as the social norm. Framing effects, the effect of perceived loss, forgone gain and gain should be reflected when policies are communicated. Governments act in a situation of high uncertainty, and thus, need to be prepared for possible future scenarios to avoid surprises. In order to accept future economic sacrifices and ensure solidarity in the society, policy measures need not only planned, justified and communicated, but records of measures and justifications shall be kept to prevent from hindsight biases. 
References

Abeler, J., \& Jäger, S. (2015). Complex tax incentives. American Economic Journal: Economic Policy, 7(3), 1-28.

Adams-Prassl, A., Boneva, T., Golin, M., \& Rauh, C. (2020). Inequality in the impact of the coronavirus shock: Evidence from real time surveys. Journal of Public Economics, 189, 104245. doi:10.1016/j.jpubeco.2020.104245

Adhikari, B., Alm, J., Collins, B., Sebastiani, M., \& Wilking, E. (2020). Using a natural experiment in the taxicab industry to analyze the effects of third-party income reporting. Department of Economics Working Paper, Tulane University, 1.

Adhikari, B., Alm, J., \& Harris, T. F. (2020). Small business tax compliance under third-party Reporting. Department of Economics Working Paper, Tulane University, 1.

Allingham, M. G., \& Sandmo, A. (1972). Income tax evasion: A theoretical analysis. Journal of Public Economics, 1(3-4), 323-338.

Alm, J. (2012). Measuring, explaining, and controlling tax evasion: Lessons from theory, experiments, and field studies. International Tax and Public Finance, 19(1), 54-77.

Alm, J. (2019). What motivates tax compliance? Journal of Economic Surveys, 33(2), 353388.

Alm, J., Bloomquist, K. M., \& McKee, M. (2017). When you know your neighbour pays taxes: Information, peer effects and tax compliance. Fiscal Studies, 38(4), 587-613.

Alm, J., Jackson, B., \& McKee, M. (1992). Deterrence and beyond: Toward a kinder, gentler IRS. In J. Slemrod (Ed.), Why people pay taxes: Tax compliance and enforcement (pp. 311-329). University of Michigan Press.

Alm, J., \& Torgler, B. (2011). Do ethics matter? Tax compliance and morality. Journal of Business Ethics, 101(4), 635-651.

Amberger, H., Eberhartinger, E., \& Kasper, M. (2016). Tax-rate biases in tax-planning decisions: experimental evidence. WU International Taxation Research Paper Series, (2016-01), 1-47.

Baker, S. R., Farrokhnia, R. A., Meyer, S., Pagel, M., \& Yannelis, C. (2020). Income, liquidity, and the consumption response to the 2020 economic stimulus payments.

Beers, T., LoPresti, E., \& San Juan, E. (2012). Factors Influencing Voluntary Compliance by Small Businesses: Preliminary Survey Results: National Taxpayer Advocate Annual Report to Congress. 
Benzarti, Y., \& Carloni, D. (2019). Who really benefits from consumption tax cuts? Evidence from a large VAT reform in France. American Economic Journal: Economic Policy, 11(1), $38-63$.

Benzarti, Y., Carloni, D., Harju, J., \& Kosonen, T. (2017). What goes up may not come down: asymmetric incidence of value-added taxes. National Bureau of Economic Research, 1101.

Bethmann, I., Jacob, M., \& Müller, M. A. (2018). Tax loss carrybacks: Investment stimulus versus misallocation. The Accounting Review, 93(4), 101-125.

Blaufus, K., Bob, J., Hundsdoerfer, J., Kiesewetter, D., \& Weimann, J. (2013). Decision heuristics and tax perception - An analysis of a tax-cut-cum-base-broadening policy. Journal of Economic Psychology, 35, 1-16.

Blaufus, K., Bob, J., Otto, P. E., \& Wolf, N. (2017). The effect of tax privacy on tax compliance-An experimental investigation. European Accounting Review, 26(3), 561-580.

Blaufus, K., Chirvi, M., Huber, H.-P., Ralf Maiterth, \& Sureth-Sloane, C. (2020). Tax misperception and its effects on decision making - A literature review. Working Paper, 150.

Blaufus, K., \& Milde, M. (in press). Tax misperceptions and the effect of informational tax nudges on retirement savings. Management Science, 1-36.

Blaufus, K., \& Möhlmann, A. (2014). Security returns and tax aversion bias: Behavioral responses to tax labels. Journal of Behavioral Finance, 15(1), 56-69.

Blaufus, K., \& Ortlieb, R. (2009). Is simple better? A conjoint analysis of the effects of tax complexity on employee preferences concerning company pension plans. Schmalenbach Business Review, 61(1), 60-83.

Blumkin, T., Ruffle, B. J., \& Ganun, Y. (2012). Are income and consumption taxes ever really equivalent? Evidence from a real-effort experiment with real goods. European Economic Review, 56(6), 1200-1219.

Bolton, G. E., Ockenfels, A., \& Stauf, J. (2015). Social responsibility promotes conservative risk behavior. European Economic Review, 74, 109-127.

Boulding, K. E. (1981). A preface to grants economics: The economy of love and fear: New York: Praeger. 
Boylan, S. J., \& Frischmann, P. J. (2006). Experimental evidence on the role of tax complexity in investment decisions. Journal of the American Taxation Association, 28(2), 69-88.

Cabral, M., \& Hoxby, C. (2012). The hated property tax: salience, tax rates, and tax revolts. NBER Working Paper Series, (18514), 1-32.

Cameron, L., \& Shah, M. (2015). Risk-taking behavior in the wake of natural disasters. Journal of Human Resources, 50(2), 484-515.

Caplin, A., Csaba, D., Leahy, J., \& Nov, O. (2020). Rational inattention, competitive supply, and psychometrics. The Quarterly Journal of Economics, 135(3), 1681-1724.

Chambers, V., \& Spencer, M. (2008). Does changing the timing of a yearly individual tax refund change the amount spent vs. saved? Journal of Economic Psychology, 29(6), 856862.

Chan, H. F., Ferguso, N., Savage, D. A., Stadelmann, D., \& Torgler, B. (2020). Is science able to perform under pressure? Insights from COVID-19. Center for Research in Economics, Management and the Arts (CREMA), 2020-07.

Chang, O. H., \& Schultz, J. J. (1990). The income tax withholding phenomenon: Evidence from TCMP data. Journal of the American Taxation Association, 12(1), 88-93.

Chetty, R., Friedman, J. N., Leth-Petersen, S., Nielsen, T. H., \& Olsen, T. (2014). Active vs. passive decisions and crowd-out in retirement savings accounts: Evidence from Denmark. The Quarterly Journal of Economics, 129(3), 1141-1219.

Chetty, R., Looney, A., \& Kroft, K. (2009). Salience and taxation: Theory and evidence. The American Economic Review, 99(4), 1145-1177.

Cialdini, R. B., \& Goldstein, N. J. (2004). Social influence: Compliance and conformity. Annual Review of Psychology, 55, 591-621.

Coibion, O., Gorodnichenko, Y., \& Weber, M. (2020). How Did US Consumers Use Their Stimulus Payments?

Craig, A. C., \& Hines Jr, J. R. (2020). Taxes as Pandemic Controls. Working Paper, 1001, 122.

Crossley, T. F., Low, H. W., \& Sleeman, C. (2014). Using a temporary indirect tax cut as a fiscal stimulus: evidence from the UK. IFS Working Papers, (W14/16), 1-32.

Cui, W., Hicks, J., \& Xing, J. (2019). Cash on the table? Imperfect take-up of tax incentives and firm investment behavior. Working Paper, 1-57. 
Devereux, M. P., Güçeri, İ., Simmler, M., \& Tam, E. H. F. (2020). Discretionary fiscal responses to the Covid-19 pandemic. Oxford Review of Economic Policy, 1-17.

Devine, D., Gaskell, J., Jennings, W., \& Stoker, G. (2020). Trust and the Coronavirus Pandemic: What are the Consequences of and for Trust? An Early Review of the Literature. Political Studies Review. Retrieved from doi.org/10.1177/1478929920948684

Edgerton, J. (2010). Investment incentives and corporate tax asymmetries. Journal of Public Economics, 94(11-12), 936-952.

Eichfelder, S., Jacob, M., \& Schneider, K. (2020). Do tax incentives reduce investment quality? Available at SSRN 3515852, 1-44.

Elffers, H., \& Hessing, D. J. (1997). Influencing the prospects of tax evasion. Journal of Economic Psychology, 18(2-3), 289-304.

Engström, P., Nordblom, K., Ohlsson, H., \& Persson, A. (2015). Tax compliance and loss aversion. American Economic Journal: Economic Policy, 7(4), 132-164.

Epley, N., Mak, D., \& Idson, L. C. (2006). Bonus or rebate?: The impact of income framing on spending and saving. Journal of Behavioral Decision Making, 19(3), 213-227.

Falkinger, J., \& Walther, H. (1991). Rewards versus penalties: on a new policy against tax evasion. Public Finance Quarterly, 19(1), 67-79.

Falsetta, D., Rupert, T. J., \& Wright, A. M. (2013). The effect of the timing and direction of capital gain tax changes on investment in risky assets. The Accounting Review, 88(2), 499520 .

Falsetta, D., \& Tuttle, B. (2011). Transferring risk preferences from taxes to investments. Contemporary Accounting Research, 28(2), 472-486.

Feld, L., Frey, B., \& Torgler, B. (2006). Rewarding honest taxpayers. In Henk Elffers, Peter Verboon and Wim Huisman (Ed.), Managing and Maintaining Compliance (pp. 45-61). The Hague: Boom Legal Publishers.

Feld, L. P., \& Frey, B. S. (2002). Trust breeds trust: How taxpayers are treated. Economics of Governance, 3(2), 87-99.

Finkelstein, A. (2009). E-ZTAX: Tax salience and tax rates. The Quarterly Journal of Economics, 124(3), 969-1010.

Fischbacher, U., Gächter, S., \& Fehr, E. (2001). Are people conditionally cooperative? Evidence from a public goods experiment. Economics Letters, 71(3), 397-404. 
Fochmann, M., Hemmerich, K., \& Kiesewetter, D. (2016). Intrinsic and extrinsic effects on behavioral tax biases in risky investment decisions. Journal of Economic Psychology, 56, $218-231$.

Fochmann, M., Hewig, J., Kiesewetter, D., \& Schüßler, K. (2017). Affective reactions influence investment decisions: Evidence from a laboratory experiment with taxation. Journal of Business Economics, 87(6), 779-808.

Fochmann, M., Kiesewetter, D., \& Sadrieh, A. (2012a). Investment behavior and the biased perception of limited loss deduction in income taxation. Journal of Economic Behavior \& Organization, 81(1), 230-242.

Fochmann, M., Kiesewetter, D., \& Sadrieh, A. (2012b). The biased effect of aggregated and disaggregated income taxation on investment decisions. Journal of Institutional and Theoretical Economics (JITE)/Zeitschrift für die gesamte Staatswissenschaft, 519-545.

Fochmann, M., Kocher, M., Müller, N., \& Wolf, N. (2019). Dishonesty and risk-taking: compliance decisions of individuals and groups. Available at SSRN 3436157, 1-52.

Frey, B. S., \& Torgler, B. (2007). Tax morale and conditional cooperation. Journal of Comparative Economics, 35(1), 136-159.

Gächter, S., \& Herrmann, B. (2009). Reciprocity, culture and human cooperation: previous insights and a new cross-cultural experiment. Philosophical Transactions of the Royal Society B: Biological Sciences, 364(1518), 791-806.

Gärling, T., Kirchler, E., Lewis, A., \& van Raaij, F. (2010). Psychology, financial decision making, and financial crises. Psychological Science in the Public Interest, 10(1), 1-47.

Gneezy, U., \& Rustichini, A. (2000). A fine is a price. The Journal of Legal Studies, 29(1), 117.

Goebel, J., Krekel, C., Tiefenbach, T., \& Ziebarth, N. R. (2015). How natural disasters can affect environmental concerns, risk aversion, and even politics: evidence from Fukushima and three European countries. Journal of Population Economics, 28(4), 1137-1180.

Goldin, J. (2012). Sales Tax Not Included: Designing Commodity Taxes for Inattentive Consumers. Yale Law Journal, 122(258), 258-301.

Goldin, J., \& Homonoff, T. (2013). Smoke gets in your eyes: Cigarette tax salience and regressivity. American Economic Journal: Economic Policy, 5(1), 302-336.

Graham, J. R., Hanlon, M., Shevlin, T., \& Shroff, N. (2017). Tax rates and corporate decision-making. The Review of Financial Studies, 30(9), 3128-3175. 
Hafiz, H., Oei, S.-Y., Ring, D. M., \& Shnitser, N. (2020). Regulating in pandemic: evaluating economic and financial policy responses to the coronavirus crisis. Boston College Law School Legal Studies Research Paper, (527).

Hartner, M., Rechberger, S., Kirchler, E., \& Schabmann, A. (2008). Procedural fairness and tax compliance. Economic Analysis and Policy, 38(1), 137.

Haushofer, J., \& Fehr, E. (2014). On the psychology of poverty. Science, 344(6186), 862867.

Hetschko, C., \& Preuss, M. (2019). Income in jeopardy: How losing employment affects the willingness to take risks. Journal of Economic Psychology, 102175.

Hofmann, E., Hoelzl, E., \& Kirchler, E. (2008). Preconditions of voluntary tax compliance: Knowledge and evaluation of taxation, norms, fairness, and motivation to cooperate. Zeitschrift für Psychologie/Journal of Psychology, 216(4), 209-217.

Hundsdoerfer, J., Sielaff, C., Blaufus, K., Kiesewetter, D., \& Weimann, J. (2013). The influence of tax labeling and tax earmarking on the willingness to contribute - A conjoint analysis. Schmalenbach Business Review, 65(4), 359-377.

Jackson, S. B., \& Hatfield, R. C. (2005). A note on the relation between frames, perceptions, and taxpayer behavior. Contemporary Accounting Research, 22(1), 145-164.

Janis, I. L. (1972). Victims of groupthink: A psychological study of foreign-policy decisions and fiascoes. Boston: Houghton Mifflin.

Kahneman, D., \& Tversky, A. (1979). Prospect Theory: a decision making under risk. Econometrica, 47(2), 263-291.

Kamenica, E. (2012). Behavioral economics and psychology of incentives. Annual Review of Economics, 4(1), 427-452.

Kan, K., Peng, S.-K., \& Wang, P. (2017). Understanding consumption behavior: Evidence from consumers' reaction to shopping vouchers. American Economic Journal: Economic Policy, 9(1), 137-153.

Kessler, J. B., \& Norton, M. I. (2016). Tax aversion in labor supply. Journal of Economic Behavior \& Organization, 124, 15-28.

Kirchler, E. (2007). The Economic Psychology of Tax Behaviour: Cambridge University Press.

Kirchler, E., Hoelzl, E., \& Wahl, I. (2008). Enforced versus voluntary tax compliance: The “slippery slope” framework. Journal of Economic Psychology, 29(2), 210-225. 
Kitchen, J., \& Knittel, M. (2016). Business use of Section 179 Expensing and bonus depreciation, 2002-2014. Office of Tax Analysis Working Paper, (110), 1-44.

Koessler, A.-K., Torgler, B., Feld, L. P., \& Frey, B. S. (2019). Commitment to pay taxes: Results from field and laboratory experiments. European Economic Review, 115, 78-98.

Kosonen, T. (2015). More and cheaper haircuts after VAT cut? On the efficiency and incidence of service sector consumption taxes. Journal of Public Economics, 131, 87-100.

Lambert, Z. V. (1978). Differential thresholds in consumer perception of retail prices. Journal of Psychology, 100(1), 139-150.

Lerner, J. S., \& Keltner, D. (2000). Beyond valence: Toward a model of emotion-specific influences on judgement and choice. Cognition \& Emotion, 14(4), 473-493.

Lerner, J. S., \& Keltner, D. (2001). Fear, anger, and risk. Journal of Personality and Social Psychology, 81(1), 146-159.

Lerner, J. S., Li, Y., Valdesolo, P., \& Kassam, K. S. (2015). Emotion and decision making. Annual Review of Psychology, 66, 799-823.

Lewis, A. (1982). The social psychology of taxation. British Journal of Social Psychology, $21(2), 151-158$.

Lozza, E., Carrera, S., \& Bosio, A. C. (2010). Perceptions and outcomes of a fiscal bonus: Framing effects on evaluations and usage intentions. Journal of Economic Psychology, $31(3), 400-404$.

Malmendier, U., \& Nagel, S. (2011). Depression babies: Do macroeconomic experiences affect risk taking? The Quarterly Journal of Economics, 126(1), 373-416.

Merritt, A. C., Effron, D. A., \& Monin, B. (2010). Moral self-licensing: When being good frees us to be bad. Social and personality psychology compass, 4(5), 344-357.

Nisan, M., \& Horenczyk, G. (1990). Moral balance: The effect of prior behaviour on decision in moral conflict. British Journal of Social Psychology, 29(1), 29-42.

Nuttin, J., \& Greenwald, A. G. (1968). Reward and Punishment in Human Learning: A Behavior Theory. New York: Academic Press.

Ostrom, E. (2005). Policies that crowd out reciprocity and collective action. In H. Gintis, S. Bowles, R. Boyd, and E. Fehr (Ed.), Moral Sentiments and Material Interests (pp. 253275). Cambridge, Mass.: MIT Press.

Pickhardt, M., \& Prinz, A. (2014). Behavioral dynamics of tax evasion-A survey. Journal of Economic Psychology, 40, 1-19. 
Politi, R. B., \& Mattos, E. (2011). Ad-valorem tax incidence and after-tax price adjustments: Evidence from Brazilian basic basket food. Canadian Journal of Economics/Revue Canadienne d'Economique, 44(4), 1438-1470.

Robben, H. S. J., Webley, P., Elffers, H., \& Hessing, D. J. (1990). Decision frames, opportunity and tax evasion: An experimental approach. Journal of Economic Behavior \& Organization, 14(3), 353-361.

Rode, J., Gómez-Baggethun, E., \& Krause, T. (2015). Motivation crowding by economic incentives in conservation policy: A review of the empirical evidence. Ecological Economics, 117, 270-282.

Rupert, T. J., Single, L. E., \& Wright, A. M. (2003). The impact of floors and phase-outs on taxpayers' decisions and understanding of marginal tax rates. Journal of the American Taxation Association, 25(1), 72-86.

Rupert, T. J., \& Wright, A. M. (1998). The use of marginal tax rates in decision making: The impact of tax rate visibility. Journal of the American Taxation Association, 20(2), 83-99.

Sachdeva, S., Iliev, R., \& Medin, D. L. (2009). Sinning saints and saintly sinners: The paradox of moral self-regulation. Psychological Science, 20(4), 523-528.

Sahm, C. R., Shapiro, M. D., \& Slemrod, J. (2012). Check in the mail or more in the paycheck: does the effectiveness of fiscal stimulus depend on how it is delivered? American Economic Journal: Economic Policy, 4(3), 216-250.

Sausgruber, R., \& Tyran, J.-R. (2005). Testing the Mill hypothesis of fiscal illusion. Public Choice, 122(1), 39-68.

Schepanski, A., \& Shearer, T. (1995). A prospect theory account of the income tax withholding phenomenon. Organizational Behavior and Human Decision Processes, 63(2), 174-186.

Shu, L. L., Gino, F., \& Bazerman, M. H. (2011). Dishonest deed, clear conscience: When cheating leads to moral disengagement and motivated forgetting. Personality and Social Psychology Bulletin, 37(3), 330-349.

Smith, K. W., \& Stalans, L. J. (1991). Encouraging tax compliance with positive incentives: A conceptual framework and research directions. Law \& Policy, 13(1), 35-53.

Snowden, F. M. (2019). Epidemics and Society: From the Black Death to the Present: Yale University Press.

Srinivasan, T. (1973). Tax evasion: A model. Journal of Public Economics, 2(3), 339-346. 
Taubinsky, D., \& Rees-Jones, A. (2018). Attention variation and welfare: Theory and evidence from a tax salience experiment. The Review of Economic Studies, 85(4), 24622496.

Thaler, R. H. (1990). Anomalies: Saving, fungibility, and mental accounts. Journal of Economic Perspectives, 4(1), 193-205.

Thibaut, J. W., \& Walker, L. (1975). Procedural Justice: A Psychological Analysis: L. Erlbaum Associates.

Torgler, B. (2002). Speaking to theorists and searching for facts: Tax morale and tax compliance in experiments. Journal of Economic Surveys, 16(5), 657-683.

Torgler, B. (2003). Beyond punishment: A tax compliance experiment with taxpayers in Costa Rica. Revista de Análisis Económico, 18(1), 27-56.

Torgler, B. (2007). Tax Compliance and Tax Morale: A Theoretical and Empirical Analysis: Edward Elgar Publishing.

Torgler, B., Demir, I. C., Macintyre, A., \& Schaffner, M. (2008). Causes and consequences of tax morale: An empirical investigation. Economic Analysis and Policy, 38(2), 313-339.

Tversky, A., \& Kahneman, D. (1991). Loss aversion in riskless choice: A referencedependent model. The Quarterly Journal of Economics, 106(4), 1039-1061.

Tyler, T. R. (1987). Conditions leading to value-expressive effects in judgments of procedural justice: A test of four models. Journal of Personality and Social Psychology, 52(2), 333344.

van Bavel, J. J., Baicker, K., Boggio, P. S., Capraro, V., Cichocka, A., Cikara, M., ...Druckman, J. N. (2020). Using social and behavioural science to support COVID-19 pandemic response. Nature Human Behaviour, (4), 460-471.

Weber, M., \& Schram, A. (2017). The non-equivalence of labour market taxes: A real-effort experiment. The Economic Journal, 127(604), 2187-2215.

Zhong, C.-B., \& Liljenquist, K. (2006). Washing away your sins: Threatened morality and physical cleansing. Science, 313(5792), 1451-1452.

Zunin, L. M., \& Myers, D. (2000). Training manual for human service workers in major disasters. Washington, DC: Department of Health and Human Services.

Zwick, E. (in press). The costs of corporate tax complexity. American Economic Journal: Economic Policy, 1-42. 
Zwick, E., \& Mahon, J. (2017). Tax policy and heterogeneous investment behavior. The American Economic Review, 107(1), 217-248. 